\title{
Changes of Meaning in Rejang Language
}

\author{
Neza Epriani \\ Institut Agama Islam Negeri Bengkulu \\ nezalebong@gmail.com \\ Kasmantoni \\ Institut Agama Islam Negeri Bengkulu \\ Kasmantoni1975@gmail.com \\ Heny Friantary \\ Institut Agama Islam Negeri Bengkulu \\ Henyfriantary30@gmail.com
}

\begin{abstract}
This study aims to describe changes in meaning and the factors that cause changes in the meaning of the Rejang language in Ujung Tanjung Dua Village, Lebong Regency. The research method used in this study is a qualitative research method. Data collection techniques used are observation, interviews, and documentation. The results of this study indicate that the change in meaning extends to the Rejang language which consists of six vocabularies, namely (1) awas, (2) Carai, (3) Esep, (4) Gen, (5) Gonong, (6) Mlai, the form of change in the meaning of amelioration consists of fifteen vocabularies, namely (1) Stir, (2) Inok, (3) Bisay, (4) Beleseng, (5) Bolon, (6) Ubo, (7) Danua, (8) Ganau, (9) Gupuak, (10) Jalet, (11) Nasea, (12) Ko os, (13) Mojoa, (14) Nokoa, (Pajuak). Based on the research, it can be concluded that there is a change in the meaning of the Rejang language in Ujung Tanjung Dua Village, Lebong Regency.
\end{abstract}

Keywords: Change of meaning, Amelioration, Rejang Language.

\section{A. Introduction}

Language is the ability of humans to communicate with other humans. The role of language is very important in people's lives. Without language, you will not be able to communicate with other people. Language is a social phenomenon and is used as a means of communication between human beings. An important means of communication for all human beings. Language has different purposes and its use as a communicative social phenomenon. Either spoken or written, language plays a very important role in communication. The more rapid the development of the times, the language will experience developments and changes, especially in the meaning of the language itself. We can see in this day and age, advances in technology and information, associations and differences in usage fields have an impact on language, whether it is experiencing an expansion in meaning, narrowing of meaning, increasing meaning or amelioration and pejorative, especially for words that begin to change their meaning. 
All human activities, as long as they exist as social beings who are social and cultured, then language is the only asset that is never separated. Language is a cultural work. Humans with different cultural backgrounds, usually will also have different languages. Arbitrary, productive and dynamic is the nature of language. This means that a language can continue to change with the times. We can see this development in terms of vocabulary, such as in the vocabulary of the Rejang language which is now beginning to experience changes in meaning. There is no human activity without language. Language is needed by humans. Lebong is one of the districts in the Bengkulu province (where the regional language is Rejang), the language used by the majority. The language in the Lebong area, especially in the village of Ujung Tanjung Dua, experienced changes in meaning, changes in meaning that occurred in this village were changes in meaning from local languages to Indonesian, changes in meaning due to the exchange of sensory responses, changes in meaning due to responses from language users. The residents of Lebong themselves are speakers of the Rejang language with a Rejang accent, there is no activity without the Rejang language.

Changes in meaning are included in the study of semantics. Semantics is the science of meaning. Including changes in meaning in it. Meaning is a reciprocal relationship between sound and the meaning of the word itself. That when someone hears a word then he will think about something, and if someone thinks about something then he will say something word. In semantic studies, there is a discussion of changes in meaning or also called shifts in meaning. The meaning of a word can change, the meaning is in the form of a lingual unit, both lexical meaning and grammatical meaning. Diachronically, not all words will change their meaning, but synchronously the meaning of a word can change. The Rejang language as a means of communication between the Rejang people, especially in Lebong district, precisely in the Ujung Tanjung Dua village, has begun to experience changes in the field of meaning, changes in meaning that occur in this village, namely, expansion of meaning, and changes in the assessment of the direction of amelioration. This change in meaning is due to the fact that in accordance with developments, society's need for language symbols that can represent the thoughts and feelings of the speakers. So speakers need words that are meaningful in accordance with their thoughts and feelings.

Therefore, the speaker succeeded in creating a new symbol with a new basis, it could be the result of their own manipulating, absorption from another language or utilizing vocabulary or meaning in Indonesian that they had mastered with changes and shifts. There 
was a change in meaning in the Rejang language. Changes that have occurred in this village also have positive and negative impacts on the community, seen whether the local community understands or not the changes in meaning that occur, when the community accepts and understands the changes in meaning that occur it is positive and vice versa when the community does not accept and do not understand about Changes in meaning that occur will be negative.

\section{B. Research Method}

The research method used in this study was a qualitative research method. Qualitative research method is a research procedure that produces descriptive data in the form of written or spoken words from people and observable behavior. From some of the opinions above, it can be defined that qualitative research is research that intends to interpret phenomena that occur with existing methods and produce data in the form of words and can be described. The use of qualitative descriptive methods in this study was used to describe changes in meaning in the Rejang language in Ujung Tanjung Dua Village, Lebong Regency.

\section{Result and Discussion}

\section{Result}

Based on the results of research on changes in meaning in the Rejang language in the village of Ujung Tanjung Dua. The author describes that the changes in meaning that occur in this village are changes in the meaning of generalization and changes in the meaning of amelioration. Generalization meaning change is a symptom that occurs in a word or lexeme which at first only has one meaning but later due to several factors it has other meanings. Amelioration is a process of changing meaning in which the meaning will be higher, respectful, and of better value than the previous meaning.

\section{1) Generalization meaning change}

Generalization of meaning occurs in a word that originally had one meaning but due to various factors became have other meanings.

a. The word awas In old Rejang language, it used to mean 'be careful', that is, remember, be alert. Now the word alert has generalized its meaning not only to mean 'be careful', but also means 'move over', namely action, existence. The symptom of this generalization of meaning is caused by the association factor, the relationship between a form of speech and 
something else with regard to the form of the speech, so what is meant is something else with regard to the speech. This generalization of meaning is the result of the development of the human mind as a language user, so that there is a generalization of meaning to 'move over', namely an action, existence.

An example of the use of the sentence "be careful".

1) Lok awas amen nak kakeatun ba, jibeak galok miling sesgenne.

2) "If you are in someone's place, you should be careful, watch your words, don't speak disrespectfully".

An example of the use of awas as 'move over'.

\section{1) "Awas di o beak mok kakea temot ku}

2) "Move over, that is my seat".

b. The word gen in old Rejang language means 'name'. Now the word gen has expanded its meaning not only to mean 'name', but also to mean 'what'. This symptom of meaning generalization is caused by the need for a new word. People need this gene word to represent the concept they want. This expansion of meaning is the result of the development of the human mind as a language user, so that there is a generalization of meaning, not only meaning 'name' but also meaning 'what', namely a question word to ask the name, type, nature.

Example of the use of gen as 'name'.

1) Api gen nu?

2) "What is your name?

Example of the use of gen as 'what'.

1) Gen nmien пи $о$ ?

2) "What do you bring?

c. The word carai in the Rejang language used to have the meaning of 'search', that is, something that has been promised (determined) must first be fulfilled. Now the word carai has generalized its meaning not only to mean 'looking for', but also 'looking for money'. The symptom of this generalization of meaning is caused by the need for a new word. People need the word carai to represent the concept they want. This generalization of meaning is the result of the development of the human mind as a language user, so that there is a generalization of meaning to 'making money'.

Example of the use of carai 'search'. 


\section{1) Carai janoba selawei o nano gi?}

2) What is she looking for?

Eample of the use of carai 'making money'.

\section{1) Carai moi ipe bak nu?}

2) Where does your father make money?

d. The word esep in the Rejang language used to mean 'suction', i.e. inserting (pulling in) with the force of the air; draw in until absorbed, inhale, suck in. Now the word esep has generalized its meaning not only to mean 'suction', but also to mean 'cigarette', namely a roll of tobacco (approximately the size of a pinkie) wrapped (nipah leaf, paper). This symptom of meaning egeneralization is caused by the need for a new word. People need esep words to represent the concepts they want. This generalization of meaning is the result of the development of the human mind as a language user, so that there is a generalization of meaning to not only mean 'suction' but also means 'cigarette', namely a roll of tobacco (approximately as big as a pinkie) wrapped (nipah leaf, paper).

Example of the use of esep 'suction'.

1) Nyoku esep es nu didik e.

2) Let me suck your ice a little.

Example of the use of esep 'cigarette'.

\section{1) Nah esep.}

2) Take this cigarette.

e. The word gonong in the Rejang language used to mean 'bald', meaning no hair (about people's heads). Now the word gonong has generalized its meaning not only to mean 'bald', but also means 'envy', which means feeling less happy to see other people's strengths (lucky and so on). This symptom of meaning generalization is caused by the need for a new word. People need the word gonong to represent the concept they want. This generalization of meaning is the result of the development of the human mind as language users, so that there is a generalization of meaning that does not only mean 'bald' but also means 'envy'..

Example of the use of gonong 'bald'

1) Ualau semaney o gonong.

2) That man's head is bald.

Example of the use of gonong 'envy' 


\section{1) Si ba gonong da puce tun tmukua stom blau.}

2) He is being envious because someone buy a new car.

f. The mlai vocabulary in the Rejang language used to have the meaning of 'to raise', which is to make (cause, increase) big. Now the word mlai has genralized its meaning not only to mean 'to raise', but also to mean 'the feeling of wanting to vomit. Symptoms of the generalization of meaning is caused by psychological factors. This change in meaning is related to emotion. so that there is a generalization of meaning not only meaning 'to raise up' but also meaning 'want to vomit'

Example of the use of mlai 'to raise'.

1) Si dewek mlai anok neda.

2) She herself raised her child.

Example of the use of mlai 'want to vomit'.

1) Mlai isangku kmliak slawey e a.

2) I feel like throwing up when I see that girl.

\section{2) Amelioration Meaning Change}

Amelioration occurs when a word has a meaning that has a better value and connotation than the previous meaning. Amelioration is a change in the meaning of a word that makes the word more polite, more polite than the word used before.

a) The word aduk, underwent a change in meaning, this vocabulary was inherited by experiencing the refinement of meaning to become sematen which means 'husband' is a man who becomes a woman's official life partner. In the Rejang language, the sematen vocabulary is considered more polite than the word aduk, here there is a change in the meaning of the sense values. Aduk which means men are against when having sex with husband and wife (taboo). Symptoms of the expansion of meaning is caused by psychological factors. This change in meaning is related to the taboo due to subtlety.

b) The word inok, undergoes a change in meaning, this vocabulary is inherited by experiencing the refinement of meaning to become mak, which means 'mother' is a woman who has given birth to someone (a child). In the Rejang language, the vocabulary of mak is considered to be more polite than the word inok, here there is a change in the meaning of the sense values. Inok which means the woman who is the breadwinner of the family. This expansion of meaning is caused by psychological factors. This change in meaning is related to the taboo due to subtlety. 
c) The word bisai, undergoes a change in meaning, this vocabulary is inherited by experiencing the refinement of meaning to become teneylay, which means 'pregnant' is in a state of carrying a child in the stomach. In the Rejang language, the word teneylay is considered to be more polite than the word bisai, here there is a change in the meaning of the sense values. bisay which tends to mean getting pregnant out of wedlock. This expansion of meaning is caused by psychological factors. This change in meaning is related to the taboo due to subtlety.

d) The word bleseng, underwent a change in meaning, this word was inherited by experiencing the refinement of meaning to become coa bajau, which means 'naked' without clothes. In the Rejang language the word coa bajau is considered more subtle than the word bleseng, here there is a change in the meaning of the taste values. Bleseng which means someone who does not wear clothes after committing lewd acts. This expansion of meaning is caused by psychological factors related to emotions.

e) The word bolon, undergoes a change in meaning, this word is inherited by experiencing a refinement of the meaning to become sakit, which means feeling uncomfortable in the body or body part because of suffering from something (fever, stomach ache, and so on). In the Rejang language, the word sakit is considered to be more subtle than the word bolon, here there is a change in the meaning of taste values. Bolon which means someone who is suffering from an incurable disease / someone who is close to death. This expansion of meaning is caused by psychological factors. This change in meaning is related to the taboo due to subtlety.

f) The word $u b o$, undergoes a change in meaning, this word is inherited by experiencing the refinement of the meaning to become bodong, which means 'stupid' which means not understanding quickly; not easy to know or can not (doing and so on). In the Rejang language the word bodong is considered more subtle than the word $u b o$, here there is a change in the meaning of taste values. ubo which means someone who is very stupid who can not be relied on at all. This expansion of meaning is caused by psychological factors related to emotions.

g) The word danua, underwent a change in meaning, this word was inherited by undergoing a refinement of meaning to become tey, which means human feces. In the Rejang language, the word tey is considered more subtle than the word danua, here there is a change in the meaning of the sense values. danua which has a very dirty and smelly 
meaning. This expansion of meaning is caused by psychological factors. This change in meaning is related to the taboo due to subtlety.

h) The word ganau, undergoes a change in meaning, this word is inherited by experiencing a smoothing of meaning to become ribut which means very busy, a lot of work so that it makes noise. In the Rejang language, the word ribut is considered more subtle than the word ganau, here there is a change in the meaning of the taste values. ganau which means chaos chaos. This expansion of meaning is caused by psychological factors related to emotions.

i) The word gupuak, underwent a change in meaning, this word was inherited by experiencing a refinement of meaning to payeak, which means tired. In the Rejang language, the word payeak is considered more subtle than the word gupuak, here there is a change in the meaning of the taste values. gupuak which means someone who is lying helpless anymore. This expansion of meaning is caused by psychological factors. This change in meaning is related to taboo because it is related to emotion.

j) The word jalet, underwent a change in meaning, this word was inherited by experiencing the refinement of the meaning to become butut, which means the buttocks, namely the groin on the back. In the Rejang language the word butut is considered to be more subtle than the word jalet, here there is a change in the meaning of taste values. jalet which means buttocks is considered rude because it is considered dirty by the people of Rejang. This expansion of meaning is caused by psychological factors. This change in meaning is related to the taboo due to subtlety.

k) The word nasea, underwent a change in meaning, this word was inherited by experiencing the refinement of the meaning to become knubua, which means to bury into the grave; implant corpses; bury. In the Rejang language the word kenubua is considered more subtle than the word nasea, here there is a change in the meaning of the taste values. Nasea which means the activity of stepping on people until they are buried in the ground is considered disrespectful because it has a sense of value that causes people to be offended. This expansion of meaning is caused by psychological factors. This change in meaning is related to the taboo with emotions.

1) The word ko os, underwent a change in meaning, this word was inherited by undergoing a refinement of meaning to become ngey, which means dirty. In the Rejang language the word ngey is considered more polite than the word ko os, here there is a change in the 
meaning of the taste values. Ko os which means an appearance that hurts the eyes because it is very dirty and disgusting, causing people to be offended. This expansion of meaning is caused by psychological factors. This change in meaning is related to the taboo with emotion.

$\mathrm{m})$ The word mojoa, underwent a change in meaning, this word was inherited by experiencing a refinement of meaning to become mpek, which means to put. In the Rejang language, the word mpek is considered more polite than the word mojoa, here there is a change in the meaning of taste values. Mojoa which means the activity of removing the male genitals or placing the genitals when urinating. This expansion of meaning is caused by psychological factors. This change in meaning is related to taboo because it wants refinement of words.

n) The word nokoa, underwent a change in meaning, this word was inherited by experiencing the refinement of meaning to nlatok, which means. Beaten by one person. In the Rejang language, the word nlatok is considered more polite than the word nokoa, here there is a change in the meaning of taste values. nokoa which means the activity of beating someone until they are seriously injured, this word nokoa represents people who want revenge. This expansion of meaning is caused by psychological factors, this change in meaning is related to emotions.

o) The word pajuak, underwent a change in meaning, this word was inherited by experiencing the refinement of meaning to kemuk, which means food. In the Rejang language, the word kmuk is considered more polite than the word pajuak, here there is a change in the meaning of taste values. Pajuak which means the mention of animal food. This expansion of meaning is caused by psychological factors, this change in meaning is related to emotions.

\section{Discussion}

Semantics studies the meaning of language or semantics examines the meaning conveyed through language. This limitation is necessary because meaning can be found everywhere. The word red in the Indonesia Dictionary means a basic color similar to the color of blood, but in the past it means to stop, in relation to sangsaka it means courage, in other situations it may mean danger, anger, and so on. Other meanings such as symbolic meaning, iconic meaning, or indexical meaning are studied in the field of semiotics. 
The shift from the present to the desired future in an environment (Abdul Hakim 2015). Change is an act of improving conventional ways of thinking and behavior or moving from the status quo that is implied in changing goals or visions that are different from before (Wagner and Hollenback, Abdul Hakim: 2015). Furthermore, Robinns stated that change becomes very broad in meaning because it can be applied to show changes in all aspects, as changes in individual groups and the totality of the organization in response to internal and external factors. The meaning of a word as diachronic allows it to change. A word which in the past has the meaning of $\mathrm{A}$ at this time can change to the meaning of $\mathrm{B}$, and at a certain time later it has the meaning of $\mathrm{C}$ or has the meaning of $\mathrm{D}$. For example: the word sail first has the meaning of traveling by sea (water) by boat or ship run with sail power, now it means all actions to travel the sea or waters using engine-powered ships, even nuclear power. Likewise, the words and their meanings also change according to the changing times. In line with semantic changes or changes in meaning often coincide with social changes caused by fights, population shifts, technological and scientific developments, economics, culture, and various other factors.

Based on the results of research and data analysis that has been carried out in the field, it can be seen that the change in meaning in the Rejang language in the village of Ujung Tanjung Dua, Lebong district, experienced a change in the meaning of expansion and a change in the meaning of the direction of amelioration. There are six expanded words: (1) awas, (2) Carai, (3) Esep, (4) Gen, (5) Gonong, (6) Mlai, dan lima belas kata ameliorasi: (1) Aduk, (2) Inok, (3) Bisay, (4) Beleseng, (5) Bolon, (6) Ubo, (7) Danua, (8) Ganau, (9) Gupuak, (10) Jalet, (11) Nasea, (12) Ko os, (13) Mojoa, (14) Nokoa, (Pajuak).

\section{E. Conclusion}

Based on the results of the research obtained about changes in meaning in the Rejang language in the village of Ujung Tanjung Dua, Lebong district, it can be concluded that there is a change in the widespread meaning of the Rejang language which consists of six words, that words are: (1) awas, (2) Carai, (3) Esep, (4) Gen, (5) Gonong, (6) Mlai, and there is a change in the meaning of amelioration with a total of fifteen words, namely (1) Aduk, (2) Inok, (3) Bisay, (4) Beleseng, (5) Bolon, (6) Ubo, (7) Danua, (8) Ganau, (9) Gupuak, (10) Jalet, (11) Nasea, (12) Ko os, (13) Mojoa, (14) Nokoa, (Pajuak). 


\section{References}

Abdul, H. (2015). Pengelolaan Perubahan Berbasis Nilai-nilai Islami. Semarang: EF Press Digimedia.(http://research.unissula.ac.id/file/publikasi/210487014/4262Peng elolaan_Perubahan.pdf, diakses 27 november2020).

Ari, C. (2013). Analisis Medan Makna Verba Berunsur Makna Voler "Mencuri" Dalam Bahasa Prancis. Skripsi tidak diterbitkan. Yogyakarta: Universitas Negeri Yogyakarta, diakses dari (https://eprints.uny.ac.id/22093/1/Ari\%20Cahyani\%2007204244035.pdf diakses 24 november 2020).

Arasy, Nurjatmika. 2018. Perubahan Makna Kata dalam Berita Olahraga di Media Daring, Skripsi tidak diterbitkan. Jakarta: Universitas Negeri Jakarta, diakses dari (http://repository.unj.ac.id/1073/1/Skripsi\%20Arasy\%20Nurjatmika.pdf diakses 20 desember 2020).

Decca, A.Y. A. (2011). Perubahan Makna Kata Dalam Wacana Berita Politik Di Surat Kabar Jawa Pos Edisi Februari-Maret 2011. Skripsi tidak diterbitkan: Universitas Jember, diakses dari (https://repository.unej.ac.id/bitstream/handle/123456789/4259/Decca\%20Ayu\%20 Wulan\%20A.pdf?sequence=1\&isAllowed=y diakses 24 desember 2020).

Departemen Pendidikan dan kebudayaan Direktorat Sejarah dan Nilai Tradisional Proyek Inventarisasi dan Dokumentasi Kebudayaan Daerah 1980-1981. 1980-1981. Sejarah pendidikan Daerah Bengkulu. Bengkulu: Departemen Pendidikan dan kebudayaan Direktorat Sejarah dan Nilai Tradisional Proyek Inventarisasi dan Dokumentasi Kebudayaan Daerah 1980-1981.

Erwan, K. (2016). Perubahan Makna dan Faktor Penyebab Perubahan Makna Dalam Media Cetak," Journal BAHASTRA, (Online), 3(2), 4.

Friska, M.S.K. (2016). Perubahan Makna Lesikal Dalam Wacana Berita Di Situs Berita Detik.Com. Skripsi tidak diterbitkan. Jember: Universitas Jember, diakses dari (http://repository.unej.ac.id/bitstream/handle/123456789/76266/Friska\%20Marlia $\% 20$ Sukarno\%20Putri\%20100210402093-1.pdf?sequence=1\&isAllowed=y diakses 24 november 2020).

Herianah. (2014). "Bentuk Perubahan Makna Dalam Bahasa Bugis," Journal, (Online), 20(1), 3 .

Ketriyawati. (2019). Analisis Bentuk Dan Faktor Penyebab Perubahan Makna Peyorasi Dan Ameliorasi Dalam Berita Kriminal Journal Diksi, (Online), 27(2), 2.

Pateda, M. (2010). Semantik Lesikal. Jakarta: PT Rineka Cipta.

Parera, J. (2004). Teori Semantik. Jakarta: Erlangga

Ria, N. (2014). Studi Deskriptif Implementasi Muatan Lokal Bahasa Rejang Dalam Menanamkan Rasa Cinta Tanah Air Siswa Kelas Iv Sdn 04 Kecamatan Kerkap Bengkulu Utara. Skripsi tidak diterbitkan. Bengkulu: Universitas Bengkulu, 
diakses dari (http://repository.unib.ac.id/8964/1/I\%2CII\%2CIII\%2CI-14-riaFK.pdf diakses 12 desember 2020).

Rio, S, dkk., (2017). Analisis Perubahan Makna Pada Bahasa Yang Digunakan Oleh Komentator Sepak Bola Piala Presiden 2017 Kajian Semantik. Journal Widyabastra, (Online), 5(2), 21.

Samsuri. 1987. Analisis Bahasa. Jakarta: Erlangga.

Utami, A.I. (2019). Analisis Perubahan Makna Bahasa Pada Berita Politik di Media Daring Kajian: Semantik, Skripsi tidak diterbitkan. Medan: Universitas Muhammadiyah Sumatera Utara Medan, diakses dari (https://docplayer.info/199288499-Penajurnal-pendidikan-bahasa-dan-sastra.html. diakses 13 April 2021).

Wijana, I. D.P. (2015). Pengantar Semantik Bahasa Indonesia. Yogyakarta: Program Studi S2 Linguistik Fakultas Ilmu Budaya Universitas Gadjah Mada Yogyakarta. 